\title{
Democratic Constitution and Ethnic Organizations in Malawi: Preserving Good Culture or Promoting, Regionalism, Nepotism and Tribalism
}

\begin{abstract}
Willie S. D. Zeze
Nkhoma-Lilongwe, Malawi

Due to the advent of the 1994 democratic constitution particularly sections 32 and 33 which provide for every person's right to freedom of conscience, religion, belief and thought, and also to academic freedom Malawi has significantly witnessed mushroom development of tribal organizations, aiming at preserving and protecting local religious beliefs and cultural practices. The Chewa Heritage Foundation (CHEFO) and the Muhlako wa Alhomwe (MWA) are among the well-known numerous ethnic organizations through which the traditional beliefs, cultural and religious practices enjoy significant respect from Chewa and Lhomwe people. Although the new Constitution has cleared a road for the establishment of these ethnic organizations, it seems activities of all ethnic associations are significantly promoting tribalism and nepotism, in addition to being used as campaign tools by political parties. This article intends to critically assess and evaluate the role and the impact of the Chewa Heritage Foundation and Muhlako wa Alhomwe on rule of law, governance and culture in Malawi. The following question will guide the discussion: Why are the Chewa Heritage Foundation and Mulhako wa Alhomwe cultural associations while exercising their constitutional rights promoting tribalism, regionalism and nepotism and used as campaign machinery by both opposition and ruling political parties? Its hypothesis is, in spite of preserving protecting cultural practices as guaranteed in constitution, tribal organizations need to be watchful so that they should not promote tribalism, nepotism and being used as campaign tools by crooked and opportunist politicians.

Keywords: democratic constitution, culture, regionalism, nepotism and tribalism
\end{abstract}

\section{Introduction}

To set the discussion in its rightful context it may be important to shed more light on the social, political and legal history of Malawi. This article addresses the following question: Why and how the Chewa Heritage Foundation and Mulhako wa Alhomwe while exercising their constitutional rights guaranteed in the 1994 constitution associations are significantly promoting tribalism, regionalism and nepotism and being used as campaign tools both by opposition and ruling political parties. Chirwa's remarks are worth giving serious thought as the paper unfolds:

Willie S. D. Zeze is a researcher and lecturer in Church History, Church Polity and Church Dogmatics, and a head of Department of Practical Theology at Mukhanyo Theology College in South Africa. 
Ethnicity and regionalism are more likely to surface in their glaring form under a democratic political dispensation that under an autocratic one. This is because in a democracy, any group of people are free to assert their identity and to lobby for their interests or the interests of the areas from which they come. By creating an enabling environment for particularistic interests of this nature, democracy does give rise to enormous challenges to its own survival as a nationally unifying ideology. ${ }^{1}$

The question that needs to be posed is: Who or what should be blamed for bringing regionalism, tribalism and nepotism? For sure, some may blame the democratic constitution particularly those sections that guarantee freedom of association. Some put their blame on colonial and indigenous politicians and protestant churches. Still some point their figures at main tribal leaders for politicking their positions and cultures. This clearly indicates that the problem is complex. As such there is need to tackle it from all angles.

\section{Malawi: A Multi-ethnic Nation}

Previously called British Protectorate, then Nyasaland and later Malawi lies east of Zambia, north and west of Mozambique, and south of Tanzania and has an area of 118,500 square kilometers with a population of 15 million largely made up of the Chewa, Yawo, Tumbuka, Lhomwe Tonga, Nkhonde, Ngoni, Sena, Asians and Europeans. ${ }^{2}$ Wiseman Chirwa Jere observes:

Unlike most southern African countries, Malawi does not have large enough ethnic groups that can form meaningful bases for effective political mobilization. However, ethnicity is a noticeable challenge. ${ }^{3}$

He also notes:

The country has three main ethnic, cultural, and linguistic groupings: Yao in the south, Chewa in the centre and Tumbuka in the north. In practice, there are examples of discriminatory tendencies and of divisions along regional, linguistic and ethnic fault lines; though Malawians do not for the most part openly discuss these issues and Malawi has avoided ethnic violence of the type that has plagued some of its neighbors. For example, the voting pattern in the referendum of 1993 and the elections of 1994, 1999, and 2004 have reflected regional and tribal or ethnic preferences. ${ }^{4}$

This paper does not deal with all the tribes living in Malawi but rather describes the Chewa and Lhomwe because their activities may substantially shed more light on how ethnic associations may promote bad governance, tribalism, regionalism and nepotism in the democratic nation. Perhaps the second reason is that the Chewa Heritage Foundation and Muhlako Wa Alhomwe are well established ethnic groupings in Malawi.

Since their arrival around 1500AD, the Chewa people still form the first largest population group and are mainly concentrated in the following districts surrounding the capital city of Lilongwe: Mnchinji, Kasungu,

\footnotetext{
${ }^{1}$ Chirwa, W. C. (1998). “Democracy, Ethnicity and Regionalism: The Malawian Experience, 1992-1996” page 55, in Phiri, K. M. and Ross, K. R. (eds). Democratization in Malawi: A Stocktaking. Blantyre: CLAIM

2 The President Ngwazi H. Kamuzu Banda spoke to the Women's League at State House in Blantyre on January 1st, 1970s, cyclostyled speech issued by the Malawi Government's Department of Information (Blantyre, 1970. For further information search: http://www.earth-cultures.com/cultures/people-of-malawi . Date of access: May 2, 2015

${ }^{3}$ Chirwa, W. (2014). Malawi Democracy and Political participation: Johannesburg: Open Society in Southern Africa, p. 63

Wiseman Chirwa 2014 Malawi Democracy and Political participation page 63 c.f Wiseman Chirwa "regionalism, ethnicity and the national question in Malawi", Southern Africa Political Economy Monthly, No. 8; in D. Kaspin, 1995, "the Politics of ethnicity in Malawi’s Democratic transition”, Journal of Modern African Studies, Vol. 33, No. 4; B. osei-Hwedie, 1998, "the role of ethnicity in Multi-party Politics in Malawi and Zambia”. Journal of Contemporary African Studies, Vol. 16, No. 2

${ }^{4}$ Chirwa, W. (1995). "regionalism, ethnicity and the national question in Malawi". p. 53, Southern Africa Political Economy Monthly, No. 8; in D. Kaspin, 1995, "the Politics of ethnicity in Malawi’s Democratic transition”, Journal of Modern African Studies, Vol. 33, No. 4; B. osei-Hwedie, 1998, “the role of ethnicity in Multi-party Politics in Malawi and Zambia”. Journal of Contemporary African Studies, Vol. 16, No. 2.
} 
Ntchisi, Dowa, Salima, Nkhotakota and Dedza. Malawi’s first indigenous President, Hasting Kamuzu Banda made Chewa's language a national language despite the fact it is largely spoken in some provinces of Zambia and Mozambique. ${ }^{5}$ Central province, the Chewas strong hold is widely believed to be the political power base of the oldest political party, Malawi Congress Party (MCP) that during the Dictator Ngwazi Kamuzu Banda’s 31 years the Chewa enjoyed a bigger and better share of appointments in key government positions. ${ }^{6}$ Since the Chewa tribe in some fundamental respects is the largest ethnic group as well as the custodians of the "national language” it will be important to assess and evaluate the influence the Chewa Heritage Foundation on Malawi’s social-political life.

The Malawi's second largest tribe called Yawo ${ }^{7}$ has its members mainly living in the districts of Balaka, Machinga, Mangochi, Zomba in southern region and Dedza, Nkhotakota and Salima in the central region. Early 19th century the Yawos were amassed through trading ivory and slaves to Arabs from Zanzibar. Their tribe’s leaders chose to follow Islam like their Arab trading partners rather than Christianity. Consequently, many Yao people were converted to Islam and therefore, any person from a Yao tribe is considered as a Muslim. According to the Malawi’s leading social media, Nyasatimes of 3 August 2009, from 1994 to 2004, during President Bakiri Muluzis’ rule, Malawi:

suddenly saw the construction of the so many mosques even in areas where a mosque was not required and indeed his Yawo tribe and the Muslim dress became more predominant. ${ }^{8}$

Also from a Yawo tribe, a former state president Joyce Banda at her rally held in the district of Mangochi in 2013, as a way of preserving their culture, advised the Yawo chiefs across the country to consider re-setting up their own heritage grouping called Chiwanja cha Aywo. ${ }^{9}$ Given this, it may evidently not be wrong to speculate that President had a hidden agenda of using the newly to-be formed heritage for her political mileage gain.

Currently living in the Malawi's districts of Thyolo, Mulanje, Phalombe and Zomba is the third largest ethnic group called Lhomwe. ${ }^{10}$ Moved into country in the 1930 s due to tribal wars in Mozambique, the Lhomwe people speak Lomwe, one of nine local languages which before 2008 was almost dying out. It is evidenced that during the Democratic Progressive Party-led government of late Professor Bingu wa Muthalika, the Founder and

\footnotetext{
${ }^{5}$ The Gule Wamkulu ceremonies consist of formally organized dances to admire the remarkable physical abilities of these individuals (called "Nyau”). If one has the misfortune of passing a Gule on the road, traditional behavior consists of dropping a few coins for the Gule-never handing them the money directly for fear they will grab you and take you to the cemetery for ritual purposes. Masks worn by the Gule Wamkulu include thousands of different representations-generally each developed hundreds of years ago by unique tribes, and accented with their own individual touch. Today, these masks, with their different origins, are part of what is now the Chewa culture.

6 The Nyasatimes Reporter, http://www.nyasatimes.com/2013/06/28/kamanya-irks-lilongwe-chiefs-for-abusing-gule-wamkulu/ Date of access April 6, 2015.

7 There are conflict views about the second largest tribe. During Bakiri Muluzi, it was alleged that Yawo was the second largest tribe. Later soon after Bingu wa Muthalika had ascended into power, it is claimed that the Lhomwe is the second largest tribe. Personally I suspect that these claims are politically motivated.

8 The Nyasatimes Reporter, http://www.nyasatimes.com/2009/08/03/lomwe-becomes-buzz-word-for-malawis-employment-business/ Date of access: May 2, 2015.

9 The Nyasatimes Reporter, Malawi Leader advises Yawo Chiefs to hold Heritage Indaba, http://www.nyasatimes.com/2013/11/03/malawi-leader-advises-yao-chiefs-to-hold-heritage-indaba/ Date of access: May 2, 2015.

10 The Hlomwe after Bingu wa Muthalika became State President of the Republic of Malawi is said to be the second largest tribe in Malawi. There is no statistical proof of this claim at present.
} 
the first Patron of the Mulhako wa Alhomwe (MWA), all high government portfolios were allocated to the members of his ethnic organizations. ${ }^{11}$ It is the aim of this paper to assess and evaluate the social-political impact the Lhomwe Heritage in Malawi for the past seven years in matters of development of nepotism and tribalism.

Tumbukas, the fourth and predominant ethnic group in the northern region of Malawi speaks Chitumbuka, a Bantu language similar in structure to Swahili widely spoken in Kenya, Tanzania, Burund and Rwanda and other neighboring. The Mzimba Heritage Association (MHA) the only ethnic association in the northern region currently running Ngoni classes throughout Mzimba with an aim of preserve and protecting Ngoni culture. ${ }^{12}$ According to Nyasatimes, because there are more technocrats from the regional who are educated, the northerners occupy most of high positions in public service and civil society organizations. ${ }^{13}$ This is speculate to be the influence of the MHA, a thing that to a certain extent contributes to prevalent problems of tribalism and nepotism especially in the business and employment sector in Malawi.

Also moved into Malawi around 1930 due to tribal wars in South Africa, is the fifth largest ethnic group called Ngoni. In the country they got settled predominantly in the districts of Mzimba in the northern region, Nchisi, Dedza and Ntchewu in the central region, Neno and Mwaza districts in the south region. They were famous for their passion for eating of roasted meat, traditional beer drinking, wearing of animal skins, patrilineal culture, polygamy and local tribal wars. ${ }^{14}$

\section{Rights and Freedom of Prticipating in Cltural-Ehnic Lfe 1891-1994}

Malawi got its independence from Britain in 1964 and had its first multiparty democratic constitution voted into a full force on May 16, $1994 .{ }^{15}$ During the pre-colonial era (before 1891), the country was occupied by a wide range of ethnic groups, each with own cultural rights and freedoms guaranteed to its subjects. Obviously, elements of good human rights and freedoms of cultural association were undoubtedly present but were outweighed by undemocratic features of the day. This might be the reason why the Chewa Heritage and Mulhako wa Alhomwe and other heritages after 2005 established mainly to preserve their customs, values and traditions of their tribes.

After 1891 Colonial rule brought no fundamental improvement in the state of cultural freedoms, introducing undemocratic features of its own. Since 1921 Malawi is divided into Northern, Central and Southern Regions, each with one dominant tribe used as a symbol of regionalism, nepotism and tribalism. ${ }^{16}$ These divisions reflected not merely administrative convenience of the day, but also different ethnic grouping activities.

11 The Nyasatimes Reporter, Lhomwe Becomes Buz Word for Malawi's employment Business, Nyasatimes http://www.nyasatimes.com/2009/08/03/lomwe-becomes-buzz-word-for-malawis-employment-business/cf

http://www.nyasatimes.com/2011/10/08/mulhako-brings-forward-celebrations-oct-23rd/ D ate of access April 6, 2015.

12 Mzati Nkolokosa http://mzatinkolokosa.blogspot.com/2008/10/our-dying-languages.html Date of access: May 2, 2015.

13 Refer to http://www.nyasatimes.com/2011/08/31/tribal-war-disguised-as-battle-for-governance-economic-issues/ Date of access: May 2, 2015.

${ }^{14}$ There are small populations of Asian and European people living mainly in the cities of Blantyre, Lilongwe, Mzuzu and Zomba.

${ }^{15}$ Constitution was drafted by the Constitutional Subcommittee of the National Consultative Council (NCC) between January and May 1994. Parts were amended in plenary sessions of the NCC in April and May 1994.

${ }_{16}$ Leroy Vail and Landeg White, Tribalism in the Political History of Malawi blishing.cdlib.org/ucpressebooks/view?docId=ft158004rs\&chunk.id=nsd0e3729\&toc.id=endnotes\&toc.depth=1\&brand=eschol\&a nchor.id=d0e3743\#Xblishing.cdlib.org/ucpressebooks/view?docId=ft158004rs\&chunk.id=nsd0e3729\&toc.id=endnotes\&toc.dept h=1\&brand=eschol\&anchor.id=d0e3743\#X Date of access April 6, 2015. 
Such geographical division thus provides a useful framework for a study of the manner in which ethnic-politics surfaced through their establishment and role. This paper is paying its attention on the Chewa Heritage and Mulhako wa Alhomwe after 2005.

Perhaps one of the important development in the history of ethnic associations, was the establishment of the various native associations between 1912 and 1944. According to Mission and Church in Malawi: The History of the Nkhoma Synod, Pauw reports:

... apart from various organizations and associations representing Europeans interests, Africans were also beginning to find opportunity to express themselves. Several Native Associations were formed from 1912 and onwards... ${ }^{17}$

For Assa Okoth in "A History of Africa: African nationalism and the de-colonisation process",

These bodies were essentially elitist in form, making it a condition of their membership that their members were to be persons of good knowledge and character and seeing their roles as one of the helpful means of developing the country in the hands of the two necessary connection like-government and governed. ${ }^{18}$

These native associations were the forerunners of the Malawi Congress Party. Interestingly they were not tribalistic and nepotistic in nature but had a national helpful agenda of fighting for the rights and freedom of the nationals.

Immediately after independence in 1964, effects of ethnic nepotism and tribalism had been surfaced. The country experienced the so-called "Cabinet Crisis" in which cabinet ministers largely from the Northern and Southern Regions felt discriminated and were sacked and finally exiled. Another appropriate symbolic signal of tribalism and nepotism appeared in 1968, when others languages were abolished as an official languages and made Chichewa as the sole national language. ${ }^{19}$ Ngulund writes:

Unity and singularity were key values in the authoritarian regime of Kamuzu Banda: One party (Malawi Congress party); one leader (Life President Kamuzu Banda); one language (Chichewa) and one Nation (Malawi). ${ }^{20}$

Perhaps it should be remembered that it was not only the languages of Chichewa or Chitumbuka that became the symbol of regionalism, nepotism and tribalism but through Chewa Heritage Foundation and Mulhako wa Alhomwe of the Lhomwe tribe. Signs of specifically ethnic thinking that contributed to political nepotism firstly existed in the pre-colonial era and continued during the colonial and post-colonial times. In his article Ethnic Revival and Language Associations in the New Malawi: The Case of Chitumbuka Gregory H. Kamwendo notes:

The so-called Cabinet Crisis of 1964 led to the removal and exile of well-educated Northerners and Southerners in Banda's government and appeared to deepen his admiration for the "Chewa culture" as the core of the Malawian nation. ${ }^{21}$

\footnotetext{
${ }^{17}$ C.M. Pauw, 1980, Mission and Church: A brief History of the Church of Central Africa Presbyterian, Nkhoma Synod, p. 15. Assa Okoth in "A History of Africa: African nationalism and the De-colonization Process, p. 140.

${ }_{18}$ Assa Okoth p. 140.

19 Assa Okoth p. 140.

${ }^{20}$ Harri Ngulundi, p. 140. Such values resonated with the postcolonial "nation-building” elsewhere. Compare, for example, Kenneth Kaunda’s “One Zambia, One Nation” slogan. In Tanzania, the Tanganyika African National Union (TANU), later called Chama Cha Mapinduzi (CCM), identified Kiswahili as having the potential to unite people of divergent ethnolinguistic origins (Gregory Kamwendo).

${ }^{21}$ Gregory H. Kamwendo, Ethnic Revival and Language Associations in the New Malawi The Case of Chitumbuka.
} 


\section{Social-Political Role of Tribal Associations After 1994}

The 1994 democratic constitution provides various forms of rights and freedoms for individual citizen and various cultural groups. Its chapter 3 (26) guarantees “every person the right to use the language and participate in the cultural life of his or her choice.” There is also a specific reference to rights and freedom of association in section 32 of the Constitution:

Every person shall have the right to freedom of association, which shall include the freedom to form associations. No one may be compelled to belong to an association.

These sections of the constitution render three things: First, according to the Constitution, Malawi is a multicultural nation and that every individual has freedom and right to join any cultural grouping. Second, although the politicians are always taking a macro view, the question of culture is a matter of individual-life choice. $^{22}$ Third, cultural ethnic differences in Malawi require a policy to avoid any form of tension.

Perhaps with due to lack of knowledge on various constitutional freedoms and rights, Malawi's ethnic groupings took some time to set their own cultural associations. Harri Engulund in A Democracy of Chameleon: Politics and Culture in the New Malawi traces the constitutional beginning of the ethnic associations:

One result of the advent of multipartism has been the provision of freedom of association, leading to the emergence of a number of voluntary associations ... These district-and village oriented association, operating the same urban centres, aim at grouping together people from the same district in order to contribute to the social and economic development in their home areas. Examples of such associations include the Friends of Machinga, the Kasungu District Development Association and Nkhatabay District Development Association.

Admittedly he goes on:

However because these associations are dominated by people of influential capacity in society-such as businessmen, academicians, clergy, politicians, then political importance may be extended beyond their apparent developmental efforts.

The question that may arise is: Is it a multipartism or the new constitution that should be blamed for breeding ethnic associations that instead of promoting the rule of law and good governance and promoting good cultural practices, they nurture tribalism and nepotism and tribal governance? Ngulund is consistent in his answer to this question.

Multipartism that must be seen as a context for the emergency of these associations. .... Multipartism appears to feed claims to specific ethno-regional identity and district oriented associations my in some cases become vehicles of political parties.

Although Ngulund may be right in his own thinking, I want to suggest that some others factors-include the new constitution and the influence of the international organisations-such as the United Nation Scientific and Cultural Organisation (UNESCO) might have led to the formation of the associations.

At its seventh General conference session held on 16 November 1972, the United Nation Scientific and Cultural Organisation noted

...that the cultural heritage and the natural heritage are increasingly threatened with destruction not only by the traditional causes of decay, but also by changing social and economic conditions which aggravate the situation with even

\footnotetext{
${ }^{22}$ Wiseman Chirwa, Nandini Patel and Fidelis Kanyongolo, 1999 Democracy Report for Malawi, p. 11.
} 
more formidable phenomena of damage or destruction. ${ }^{23}$

The Conference recalled that the Constitution of the UNESCO provides that it will maintain and assure the conservation and protection of the world's heritage, considering that the cultural property demonstrates the importance, for all the peoples of the world. ${ }^{24}$

In seeking to enhance the protection and promotion of local customs and culture by revising the Arts and Crafts, Act of 1990 and the Copyright Act of 1989 of the Malawi government gave power to ethnic communities to participate in and benefit from the safeguarding of their own intangible heritage. ${ }^{25}$ But this was not materialized until 2006 when the Chewa people set up their association.

For the purpose of monitoring all Integrated Cultural Heritage (ICH) in Malawi, the Government established a National Intangible Cultural Heritage Committee (NICHC). Members comprise of representatives of the media, academic and research institutions, Museums of Malawi, National Commission for UNESCO, Division of Arts and Crafts and non-governmental organizations working in the cultural sector as well as the heritage associations namely: Mulhako wa Alhomwe, Chewa Heritage Foundation, Mzimba Heritage Foundation and Ndamo sya Ayao. $^{26}$

The committee is chaired by Director of Culture and meets at least three times a year. Among its terms of reference is the assessment of the safeguarding measures in place for the elements and recommendation on their improvement and assisting in sourcing funding for safeguarding activities. The committee's evaluation feeds into the six year national report and monitors the implementation of safeguarding activities.

In 1980s the Malawi Government formulated a policy giving power to every ethnic group safeguard their intangible heritage. ${ }^{27}$ But it seems time was not ripe for the policy to spearhead cultural projects in the country.

\section{Chewa Heritage Foundation (CHEFO)}

Between 1994 and 2005, the United Nation Educational, Scientific Organizations (UNESCO) in collaboration with the Department of Culture conducted civic education across the country civic-educating the local tribal leaders about the rights of every citizen, freedom to association and ideals of preserving cultural customs, values and traditions and promote unity among the tribal members. In their response, the Chewa people became the first ethnic group to set up a cultural grouping called Chewa Heritage Foundation (CHEFO).

Chewa Heritage Foundation early 2006 Chewa Heritage Foundation was established with aim of preserving customs, values, and traditions across the nation with over 137 chiefs under its operation. ${ }^{28}$

Much has been written that the formation of the cultural grouping might "have been motivated by a number of factors-first being a perceived declining in moral standards as a result of the unquestionable copying of bad

\footnotetext{
${ }^{23}$ This is one the resolutions adopted by the General Conference at its seventeenth session Paris, 16 November 1972. http://whc.unesco.org/en/conventiontext Date of access April 14, 2015.

${ }_{24}$ Resolution Adopted by the General Conference at its seventeenth session Paris, 16 November 1972 http://whc.unesco.org/en/conventiontext, Date of access April, 11, 2015.

${ }^{25}$ Ninth session of the Convention for the Safeguarding of the intangible Cultural Heritage Paris, France November 2014 , page 6. http://whc.unesco.org/en/conventiontext Date of access April 12, 2015.

${ }^{26}$ Ninth session of the Convention for the Safeguarding of the intangible Cultural Heritage Paris, France November 2014 page 7.

${ }^{27}$ Ninth session of the Convention for the Safeguarding of the intangible Cultural Heritage Paris, France November 2014 , page 7.

28 Alfred Chauwa. Nyasatimes, Chewa Heritage Respond to Kabwira Appeal for Malawi flood Disaster, http://www.nyasatimes.com/2015/04/07/chewa-heriage-responds-to-kabwila-appeal-for-malawi-flood-disaster Date of access: May 2, 2015.
} 
foreign practices-to point was the showing of underwear and disrespects to the elder people."29 But is it fair enough to speculate that all immorality comes from outside Malawi o Africa?

As already noted, since at the heart of Chewa Heritage is a means to preserve the Chewa unity and identity considering that language is indeed the most critical element in the transmission of culture. ${ }^{30}$ Annually the Chewa people from the Malawi and Zambia governments celebrate their Kulamba ceremony in Katete, Zambia. ${ }^{31}$ This is an annual payment of respect to their King Gawa Undi. It is equally meant as an annual expression of unity among themselves and also other tribes who send their representatives.

Additionally, the Chewa Association provides important social services to both the Chewas and all the victims of natural disasters regardless of their ethnic grouping or region. ${ }^{32}$ This is evident as Nyasatimes reports on what happened on March 5, 2015.

Chewa Heritage Foundation has donated relief items worth MK5, 000,000.00-courtesy of Nu-Skin Force for Good Foundation to newly constructed camps in flood hit districts of Chikwawa and Nsanye. ${ }^{33}$

According to the Nyasatimes of April 7, 2015, the Heritage responded to support calls to hailstorms and flood victims in Salima North Constituency by donating various food items worth MK1,000,000.00-courtesy of Nu-Skin Force for Good Foundation based in USA-the food items included bags of maize, beans, salt and Unsipa (bonya). ${ }^{34}$

CHEFO contributes to the economy of Malawi, Mozambique and Zambia. As thousands of visitors to Kalamba celebration and exhibitions need transport, food and entertainment, restaurants, guest houses, lodges, and hotel, facility owners generate a huge sum of money and in return taxes is paid to the governments.

Given the brief history and various contributions of the Chewa foundation, there is need to remember that this cultural ethnic organization is playing an important role not only among the Chewas but to the non Chewa and the countries as a whole. In light of the success of Chewa Heritage other ethnic associations have been formed in its wake, such as Mulhako wa Alhomwe, Ndamo sya Ayawo and the Mungano wa Asena na Amang'anja. Later, we speak about how the politicians are hijacking the cultural events of Chewa Heritage and Alhomwe ethnic grouping for their political gain.

\section{Mulhako wa Alhomwe (MWA)}

Founded by Malawi’s former President late Professor Bingu wa Muthalika in 2008 the Lhomwe culture,

\footnotetext{
29 Menno Welling, article published in The Lamp Magazine, October 2014 cf. http://www.mlambefoundation.org/en/newsitems/culturewhereto.html Date of access April, 17, 2015

${ }_{30}$ Menno Welling (Published in The Lamp, October 2014, http://www.mlambefoundation.org/en/newsitems/culturewhereto.html Date of access April, 16, 2015

${ }^{31}$ Every year the Chewa Heritage receives donation of money from the State President towards the travel expenses of Malawian traditional leaders. This is a kind gesture by all Presidents regardless the fact that each he holds a different ethnic affiliation.

32 Alfred Chauwa, Nyasatimes, Chewa Heritage Donates MK5 million worth Relief Items to Flood-hit-lower Shire; http://www.nyasatimes.com/2015/03/05/chewa-heritage-donate-k5m-worth-relief-to-flood-hit-lower-shire/

33 Alfred Chauwa, Nyasatimes, Chewa Heritage Donates MK5 million worth Relief Items to Flood-hit-lower Shire; http://www.nyasatimes.com/2015/03/05/chewa-heritage-donate-k5m-worth-relief-to-flood-hit-lower-shire/

34 Alfred Chauwa, Nyasatimes, Chewa Heritage Responds to Kabwira Appeal to Malawi flood disaster, http://www.nyasatimes.com/2015/04/07/chewa-heriage-responds-to-kabwila-appeal-for-malawi-flood-disaster/ Date of access April, 24, 2015.
} 
Mulhako $^{35}$ wa Alhomwe grouping aims at developing, revitalizing and preserving the history, traditions, culture and customs of the Lhomwe people. It is also noted that the association was secondarily founded specifically

... to expose children and people from other tribes and countries to the ethnic customs such as dance, drumming, storytelling, poetry, tribal history, arts, crafts as means of promoting self-esteem, creating and preservation of the Lhomwe tribal customs. ${ }^{36}$

Commenting on his personal blog regarding the cultural freedom and rights of the Lhomwe during colonial period, Hastings Maloya wrote:

The colonial administrations were largely responsible for implementing derogatory policies and attitudes that excluded the Alhomwe from the mainstream of social and cultural evolution of this country. ${ }^{37}$

Elsewhere it is also reported that:

As labour migrants from Mozambique, they have since early colonial times been stereotyped as primitive and backward. As a result, members of the Lhomwe community have often been hiding their identities to the point of the current generation hardly speaking ChiLhomwe, or knowing Lhomwe traditions. ${ }^{38}$

Some historical notable reasons are also cited by Hastings Maloyo to explain why the Alhomwe people during President Bingu wa Muthalika established their association.

Notwithstanding the significant contributions by the tribe to the social, cultural and economic development of Malawi, documented reports and records of non-Alhomwe researchers show that the Alhomwe had always been relegated to play an insignificant role in the cultural development of this country.

He concludes by narrating how the Lhomwe people and people from other tribes lost their cultural rights.

It is not surprising therefore that Lhomwe rich traditions, culture and customs disappeared over the years, and many Lhomwe people changed their names and preferred to hid their identify in order to survive the social and cultural onslaught.

Although Maloya does not substantiate his argument as regards to how and why the colonial administration excluded the Lhomwe from the social cultural evolution of the country, it is clear that the Lhomwe people saw the presence of Lhomwe President as their advantage. Maloya is very quick to point out the implication this might have on good governance and rule of law in Malawi.

\footnotetext{
35 The meaning of the term Mulhako is itself controversial. According to Wiseman Chirwa (2014:63) the word "Mulhako" means "door" or "gateway" and to serious critics it implies the Lomwe's passage into politics, government positions, businesses and other privileges. It seems how the association might become such a "door" or "gateway" cannot be explained. Perhaps to the Lomwe, however, it may refer to "a gateway to the Lomwe culture and tradition" because "the association aimed at reviving and preserving the traditions, culture and customs of the Lomwe people through an awareness, knowledge, understanding and appreciation of their origins, roots and heritage”.

${ }^{36}$ For more information refer to http://www.nyasatimes.com/2013/10/07/mulhako-wa-alhomwe-carnival-slated-for-october-27/ Date of access April 14, 2015.

${ }^{37}$ Currently working as Programme Officer responsible for Environmental Education of, Awareness and Communication for Mulanje Mountain Conservative Trust (MMCT) since September 1, 2002, Hastings Maloya, a Seventh Day Adventist Church member comes from Chonde, Village Traditional Authority Mabuka in Mulanje district and is married with two daughters Eva and Eve. This information is a quotation from his personal blog which expresses his personal thoughts and purely his opinions. He welcomes comments and critics from readers. Hastings
} http://hastingsmaloya.blogspot.com/2012/04/bingu-high-class-leader-who-never.html Date of access March 14, 2015.

$38 \mathrm{http} / / /$ www.mlambefoundation.org/en/newsitems/mutharika.html Date of access April 26, 2015. 
The launch of the Mulhako wa Alhomwe marked as the renaissance of a culture that was dying. However, it was not all rosy as other quarters expressed fears that the group was established for political purposes. ... Bingu wa Mutharika, maintained that he never initiated the formation of the group on political grounds. "This is not a political or religious grouping," said Wa Mutharika adding, "the group is about promoting Alhomwe cultural and traditional values including our language.” Mutharika insisted that by preserving a culture, one keeps the traditions, family values, sociological standards, morals and language and maintains personal identity.

Given the history of how the Lhomwe had lost their culture only during the colonial era and also how they adapted to the situation, it is also reported that the similar problem had continued during the 31 years of the Malawi Congress Party-led government. As noted elsewhere apart from Chichewa, no language could be used in the press or on the radio, a situation which resulted in bitter resentment throughout the Northern and the South Regions.

Perhaps, the worst setback to all languages in independent Malawi was the Malawi Congress Party's 1968 convention which resolved that Chichewa be a national language. The introduction of one language was partly good for the sake of national unity. The problem was the selfish manner in which first President Dr. Hastings Kamuzu Banda imposed his language on the nation. ${ }^{39}$

The idea to unify the multicultural nation like Malawi was welcome and useful but the way how the issue was handled it was as if other tribes were cultureless. The President did not foresee its repercussion on his tribal members afterward.

Early 1990s the Malawi government gave power to communities to participate in and benefit from the safeguarding of their own intangible heritage. Immediately following the adoption of the 1994 democratic constitution a National Intangible Cultural Heritage Committee (NICHC) was established comprising academic and research institutions, Museums of Malawi, National Commission for UNESCO, Division of Arts and Crafts and ethnic groupings. Mulhako wa Alhomwe under the leadership of its founder and Patron President Bingu wa Muthalika was a prominent member of NICHC. It was on 25 October 2008, when former President, late Bingu wa Muthalika turned the situation around and brought a renaissance into the Lhomwe people.

Today Lhomwe is no longer a forgotten tribe. After reviving its cultural beliefs, traditions, language, songs, dances and the known unique cultural living, Lhomwe is now positioned on the international map, with support from United Nations. Through its Educational, Scientific and Cultural Organization (UNESCO), the world body supported the inventory of intangible cultural heritage of the Lhomwe culture at grass roots level.

Later, we will discuss how the President's role as Patron of Mulhako wa ALhomwe negatively promoted tribalism and influenced his political leadership and appointment of people to public offices.

In an attempt to achieve its objectives the Mulhako wa Alhomwe embarked on a number of programmes in Mulanje district. The grouping mobilized resources from the local people international organisations and the Democratic Progressive Party-led government of its founder and Patron.

Due to its financial constraints of the Association, government permitted the Lhomwe people, through Mulhako wa Alhomwe, to construct, with technical advice from Museums of Malawi, a Lhomwe cultural centre with performance space, a community museum, a library and a school at Chonde in Mulanje District ... for depicting Lhomwe culture and traditions as well as teaching of Lhomwe language respectively. ${ }^{40}$

\footnotetext{
${ }^{39}$ Mzati Nkolokosa, http://mzatinkolokosa.blogspot.com/2008/10/29/our-dying-languages.html Date of access April 30, 2015.

${ }^{40}$ Ninth session of the Convention for the Safeguarding of the intangible Cultural Heritage Paris, France November 2014 , p. 7.
} 
In 2010, the Malawi government through the Department of Culture in conjunction with Mulhako wa Lhomwe provided undisclosed amount of money assisting the members of the grouping to acquire and to raise domestic animals for the purposes of using their skins for making associated tangible materials such as drums, headgear and back packs, necessary for the performance of the traditional dance. ${ }^{41}$ Considering that MWA had ties with the Head of State and majority of the cabinet and the ruling party may give an impression that tribalism was a real game of the day.

Although the purpose of the Mulhako wa Alhomwe is to develop, revitalize and preserve the history, trade traditions, culture and customs of the Lhomwe people through various activities including annual Lhomwe cultural festivals, many people were suspicious with the position of the President Bingu wa Muthalika and majority of his cabinet because in their view point, they expected him as Head of state to embrace all tribes and their cultures. But paradoxically the President was looked upon as favouring people from one tribe which is synonymous with being called a tribalism. ${ }^{42}$

\section{Tribalism and Nepotism: Evaluating Contributions of CHEFO and MWA}

Nepotism is yet again at the centre of Malawian politics ... ${ }^{43}$

As already mentioned elsewhere the Chewa Heritage Foundation and Mulhako wa Alhomwe were originally established not to establish or promote regionalism, tribalism and nepotism but unifying its members, reviving, developing, promoting and preserving the traditions, culture and customs. This section critically evaluates how the ethnic groupings significantly contribute to regionalism, tribalism and nepotism.

\section{National Unity and State Building on the Basis of Tribal and Regional Lines}

Many writers of the history of Malawi have noted that problems of regionalism, tribalism and nepotism surfaced during the Malawi Congress Party rule. There are many incidents that illustrate this. According to Kasindo:

President Dr. Hasting Kamuzu Banda was widely associated with the elevation of the Chewa and their cultural language, Chichewa to majoritarian national status. ${ }^{44}$

Soon after 1994, people began holding the common view that just like inmost os Africa's post-colonial government, tribalism in Malawi was imported by colonial masters and aftermath it was perfectly nurtured by the following governments: the Malawi Congress Party, the United Democratic Party, Democratic Party, and People's Party. ${ }^{45}$ The Nyasatimes online news of 26 June 2013 was on record reporting that

During Dictator Ngwazi Kamuzu Banda’s 31 years enjoyed a bigger and better share of appointments in top government positions. This had the unfortunate consequence of other tribes mobilize to fight the common enemy who in their wisdom had decided to monopolize the country’s employment cake. ${ }^{46}$

\footnotetext{
${ }^{41}$ Ninth session of the Convention for the Safeguarding of the intangible Cultural Heritage Paris, France November 2014 , p. 8.

42 Mzati Nkolokosa, http://mzatinkolokosa.blogspot.com/2008/10/29/our-dying-languages.html Date of access April 2, 2015.

43 Margaret Jim Maravi Voce , May 11, 2012 Nepotism As Northerners Target “Lohmwe” Chief Justice Munlo Malawi Voice.mht Date of access April 2, 2015.

44 Kasindo. 1998:256-260.

45 Layson Godwin Sibande, Nyasatimes Reporter, http://www.nyasatimes.com/2014/09/03/sept-1964-how-kamuzu-banda-and-mcp-planted-seed-of-tribalism/ accessed 12 May, 2015.

${ }^{46}$ The Nyasatimes Reporter, http://www.nyasatimes.com/2013/06/28/kamanya-irks-lilongwe-chiefs-for-abusing-gule-wamkulu/ Date of access: March 2, 2015.
} 
Elements of tribalism and nepotism during the Malawi Congress Party-led government were also evidenced by Dr. Kamuzu Banda's nation and state-building ideology after the 1964 cabinet crisis. In his publication, The Politics of Tribe, Mzati Nkolokosa testified:

when the first president, Hastings Kamuzu Banda, shifted the country's capital-city from Zomba to the heartland of the Chewa people, at Lilongwe in the Central Region, and made their language into the official one of Malawi, it was a political act against the Tumbuka-speakers of the North and the Yao and Ngoni peoples of the south, however justified by the brutal logic of modern state-building. ${ }^{47}$

Although others may have a different view, an introduction of Chichewa language as a national language indeed facilitated national unity. Taking into an account, the main events in the development of Malawian politics: the 31 years of Malawi Congress party of President Kamuzu Banda, the 10 years of the United Democratic Front of President under President Bakili Muluzi and 8 years of the Democratic Progressive Party-led government under Bingu wa Muthalika, arguably Malawi did not escaped large-scale of tribalism and nepotism and ethnic leadership.

Tribalism and religion reign supreme in key-position appointment. Again history seems to be repeating itself where tribe has reigned supreme in the appointment of persons in key government positions in Malawi. $^{48}$

The question to be raised here is whether, adopting the 1994 democratic constitution meant that Malawi had escaped problems of tribalism and nepotism in matters of appointing people to public offices. To be more precise, we now need to assess and evaluate whether there were elements of tribalism and nepotism manifested during the United Democratic-led government under President Bakili Muluzi. To address this question, let's pay attention to some analytical contributions from the press.

The man who took over from Kamuzu, Bakili Muluzi started on a very good note spreading appointments to every corner of the country and at the some point there were more ministers from the north than from his own Eastern region. The country suddenly saw the construction of the so many mosques even in areas where a mosque was not required and indeed his Yawo tribe and the Muslim dress became more predominant. ${ }^{49}$

In contrast, it is further noted:

When Malawi's second president, Bakili Muluzi, made public appointments from his own Yao people, and was seen to be favouring the Yaos' Muslim faith over Christian ones, and to be building more roads and power lines in their Mangochi district than elsewhere, he was strongly criticized too. ${ }^{50}$

The two reports above provide an entry point into more discussions on the prevalent problems of tribalism and nepotism in Malawi. Importantly, we seem to have two contradicting reports regarding whether tribalism and nepotism existed during President Muluzi. According to Malawi Digest practice of nepotism and tribalism were practically manifested during the UDF regime.

47 http://maravi.blogspot.com/2009/11/nyasatimes-politics-of-tribe-in-malawi.html Date of access: March 20, 2015.

48 The Nyasatimes Reporter, http://www.nyasatimes.com/2009/08/03/lomwe-becomes-buzz-word-for-malawis-employmentbusiness/ Date of access April 14, 2015.

49 The Nyasatimes Reporter,

http://www.nyasatimes.com/2009/08/03/lomwe-becomes-buzz-word-for-malawis-employment-business/ Date of access April 14, 2015.

${ }^{50}$ http://maravi.blogspot.com/2009/11/nyasatimes-politics-of-tribe-in-malawi.html Date of access: March 3, 2015. 
Readers may wish to be reminded that during the Bakili Muluzi era, there was a time this country had Muluzi a man coming from Machinga as President, Joseph Chimbayo from Mangochi as Army Commander, Joseph Airon from Mangochi as Inspector General of Police, Alfred Upindi from Mangochi as Secretary in the Office of President and Cabinet, Lilian Patel from Mangochi as Minister of Foreign Affairs and her deputy was the late Dr Mekki Mtewa also from Mangochi. ${ }^{51}$

So far we have evidence from the social media. But one thing we must remember is that sometimes this type analytical evidence is conditioned by writer's political outlook. I want to suggest seeking evidence from a Church's point of view can be of verifying the findings.

In presenting views of the Church, in 1992 the Roman Catholic Church bishops issued a Pastoral letter, Living Our Faith in which they condemned the Malawi Congress Party led government for promoting regionalism, tribalism and nepotism in the country.

Bribery and nepotism are growing in political, economic, and social life. This causes violence and harm to the spirit of our people. Honesty, righteousness, respect, equal opportunity for all: these must be the qualities which guide our nation as it grows and develops into the future. ${ }^{52}$

In the letter the Malawi Catholic clerics continued:

One of the cornerstones of the nation is "unity". This reflects the will of our Creator that we live in mutual respect and oneness. Tribalism, apartheid (whether economic or social), regionalism and divisions are contrary to the call and truth of humankind. We call all the faithful to celebrate our common birth and destiny in mutual respect, acceptance, justice and love. $^{53}$

The Church of Central Presbyterian (CCAP) Nkhoma Synod in its 1998 Pastoral Letter, The Christian Responsibility in a Democratic Country observed "This new system of government has not produced true justice. On the contrary, tribalism and corruption has tremendously increased.”

The Letter continued advising politicians and government to desist from any form of tribalistic and nepostic tendencies:

All forms of discrimination and partisanship should be shunned. People should be treated fairly, justly and equitably particularly in court cases, the judicial system of the country has also to function in line with the rule of law and without bias (Isaiah 58: 1-11; Proverbs 29: 7, 14; Psalms 72: 1-4, 13, 14).

Also in its 2003 Pastoral Letter called, "Reconsidering the Future of Our Country, Malawi: Genuine Change Required," Nkhoma noted

There is a fair amount of discrimination and mismanagement in government appointments, based on nepotism, regionalism, tribalism and political affiliation. Preference is given to people belonging to the ruling party in the awarding of government contracts.

In his song below Lucius Banda one of the famous local Malawian muscians, Loius Banda categorically condemned regionalism and religion in politics as things that has destroyed the country and which should

51 http://malawidigest.blogspot.com/2009/09/dr-munthali-ignored.html Date of access: March 2, 2015.

52 Pastoral Letter of the Catholic Bishops of Malawi, Lent 1992, Episcopal Conference of Malawi, Lilongwe.

53 Pastoral Letter of the Catholic Bishops of Malawi, Lent 1992, Episcopal Conference of Malawi, Lilongwe.

One can recall that in March 1961, the bishops of issued a joint pastoral letter entitled "Building a Happy Nation" instructing all Catholics to rightly use their rights and responsibilities within the nascent political order. This mode of communication can be welcome but it might have contributed to biasness among Christians. 
therefore be avoided: ${ }^{54}$
Zakuti uyu wachoka kumpoto zisiike. (That one comes from the north, must stop). Zakuti uyu wachoka kumwera zisiike. (That one comes from the south, must stop). Zakuti uyu ndi mLomwe, ndi mChewa zichepe. (That one is a Lomwe, a Chewa, must stop). Tonse ndi aMalawi. Likakhala dziko ndi lathu. (We're all Malawians. If it is the country, it is for us all). Tisataye nthawi kukumbana mitundu. (We should not waste time digging up tribes). Zoti ndi msilamu achoke pa udindo. (That he is a Muslim, must be removed, won't help us). Mavuto athu ndi umphawi, si mpingo. (Our problem is poverty, not religion).

Though Banda does not mention the term "tribalism" as one of the problems, a third line indicates that tribalism is also a reality in business, politics and religion. But the survey above is an adequate proof that ethnicity contributed to nepotism and tribalism was real during President Muluzi's rule despite the adoption of the democratic constitution. Let's now highlight some events that happened during Bingu wa Muthalika's regime.

Ethnicity determining employment and business opportunities. An analysis of the middle management to the supervisory cadre has also shown an average growth of more persons from the same ethnic extraction. ${ }^{55}$

President Muthalika's role and action as founder and patron of the Mulhako wa Alhomwe and also appointing Lhomwe people to key government positions had been critiqued as tribalism and nepotism. It is now a fitting case on which to explore more evidence of Tribalism and nepotism during his rule both as State President Bingu of the Republic of Malawi and the founder and first patron of the Mulhako wa Alhomwe.

Soon after Muthalika became President of Malawi, people were convinced that there would no tribalism and nepotism in the country. ${ }^{56}$

But in a sudden and precedent development the country’s national fabric has given a sway to one tribe leadership: the minority Lhomwes under the umbrella of the Mulhako wa Alhomwe have now assumed all the power in practical all the three arms of government. ${ }^{57}$

Without citing names, the analysis indicated that during President Bingu's regime, the hiring of cabinet ministers and their deputies and principal secretaries reflected the patterned that had favoured the Lhomwe grouping. Some members of the tribe even proudly said,

It is our time to enjoy ourselves and have all good things. Others will also have their time and leadership goes to their homes. $^{58}$

To many, tribalism and nepotism was unwelcome development and warned that the trend negatively affect the children who are orn of the Lhomwe tribe.

There is more. Affirming that the issues of tribalism and nepotism were a reality as well as an ongoing

\footnotetext{
54 Mzimu wa Soldier: Contemporary Popular Music and Politics.

55 The Nyasatimes Reporter, http://www.nyasatimes.com/2009/08/03/lomwe-becomes-buzz-word-for-malawis-employmentbusiness/ Date of access April 14, 2015.

${ }^{56} \mathrm{http}: / /$ www.nyasatimes.com/2009/08/03/lomwe-becomes-buzz-word-for-malawis-employment-business/ Date of access: March 29, 2015.

${ }^{57}$ http://www.nyasatimes.com/2009/08/03/lomwe-becomes-buzz-word-for-malawis-employment-business/ Date of access: March 6, 2015.

58 http://www.nyasatimes.com/2009/08/03/lomwe-becomes-buzz-word-for-malawis-employment-business/ Date of access: March 5, 2015.
} 
practice in Malawi, one of the Lhomwe commentators, Nayeya said:

The Lhomwe may suffer when the President is out of power like what is happening to the Yawos and Chewas. The Yawos were all over and introduced bad programmes and were also taking prominent jobs and today they are in trouble. ${ }^{59}$

He rightly continued arguing that "Malawi is for everyone, good jobs must be given to every deserving citizens except small projects in the districts should be given to those that come from that district”. ${ }^{60}$

In its 2012 Pastoral Letter, Exercising Our Faith Through Prayer, in Our Time, in Our Nation the Nkhoma Synod heavily criticized the Democratic Progressive-led government for advocating tribalism and nepotism in public arena.

We have to pray for the State President and his cabinet for their health to govern this country with sober minds and concern for all Malawians without bias along tribal, regional and political party affiliations. People occupying senior public positions should be appointed only on merit. Similarly the awarding of contracts should be done fairly. It is sad to note that some ruling party leaders are openly declaring that contracts should be awarded only to ruling party members. This cannot be condoned in a democratic environment. ${ }^{61}$

In its downplaying response to the criticism, through its minister of information Patricia Kaliati, Malawi government condemned for issuing its letter not good faith citing as an example what happened at Cana when Jesus attended a wedding.

We expect them [sic pastors] to understand the Bible well. Jesus Christ when he went to a wedding in Cana and was told that there was no wine. He did not go and write a letter. He turned water into wine immediately to offer solution. Nkhoma Synod does not offer any solution. ${ }^{62}$

It seems the government admitted that the problems of tribalism and nepotism were a reality but the Church could not issue a pastoral letter by seeking an audience with the President and other government officials to express their concerns. In its concluding remarks the government took its turn criticizing the Synod for adopting a culture of silence at crucial times including during the era of the founding President the late Dr Kamuzu Banda and his predecessor Bakili Muluzi. ${ }^{63}$

These few highlights substantiate the reason why Malawi's social-political situation requires critical evaluation. But understanding how the ethnic associations operate and their ties with political parties may provide a road map for redefinition of their roles in the society.

Regionalism and ethnism, good governance and general elections. This section assesses how close ties between Chewa Heritage and the Malawi Congress Party, members of Yawo Tribe and United Democratic Party and Mulhako and Democratic Progressive Party have been mobilized to get votes from tribal members during the 2009 and 2014 general elections. As part of background, there is need also to stress the tribalism and regionalism which were prevalent problems during the United Democratic Party regime under Elson Bakili Muluzi. Tim

\footnotetext{
${ }^{59}$ http://www.nyasatimes.com/2009/08/03/lomwe-becomes-buzz-word-for-malawis-employment-business/ Date of access: March 2, 2015.

${ }^{60} \mathrm{http}: / /$ www.nyasatimes.com/2009/08/03/lomwe-becomes-buzz-word-for-malawis-employment-business/ Date of access Jan 2, 2015.

61 The CCAP Nkhoma Synod, 2012, Pastoral Letter, “Exercising Our Faith Through Prayer, in Our Time, in Our Nation”.

62 http://malawivoice.com/2012/04/03/nkhoma-synod-letter-only-motivated-by-delayed-money-kaliati-74922/

63 http://malawivoice.com/2012/04/03/nkhoma-synod-letter-only-motivated-by-delayed-money-kaliati-74922/
} 
Hughs comments:

Muluzi's UDF principally draws on the support of the most populous Yawo speaking southerners, whilst AFORD relies almost entirely on the Tumbuka Henga speaking northerners for its popular vote. Whilst MCP leader Gwanda Chakuamba hails from the south, his support base reflects the traditional dominance of the MCP in the central region. ${ }^{64}$

Although it is the intention of this paper to evaluate how the cultural groupings of the Yawo contributed to nepotism, tribalism and regionalism, but one to remember is that almost all the tribes in Malawi have significantly made an impact on the current problems.

The Alhomwe tribe has heavily been criticized for being used as the Democratic Progressive Party campaign machinery. Since its establishment the star attraction of the Lhomwe cultural festival was President Bingu wa Muthalika and cabinet and government offices. According to Nyasatimes and Maravi post newspaper of November 28, 2009 Muthalika's presence during the festivals reflected his growing use of his own ethnic identity to mobilize political support. ${ }^{65}$

It has happened that many people from southern region especially the majority of the Muhlako wa Ahlmowe threw their support behind the Democratic Progressive Party Presidential candidate. The same also happened to the Chewa of Central region where majority of them are also members of the Chewa Heritage Foundation supported the Malawi Congress Party. ${ }^{66}$

Since the introduction of multi-party elections in 1994, voting in Malawi's national elections has displayed a clear regional pattern. In the first two elections (1994 and 1999), one party dominated each of the three regions: AFORD won close to 90 percent of the north; the MCP won over 60 percent of the central region; and the UDF won around 80 percent of the south. In the most recent election (2004), this voting pattern generally persisted. ${ }^{67}$

This small sketch highlights a reality that Malawian politicians use ethnicity and ethnic associations to get votes from tribal members. Two points should be mentioned. First, one can agree with me that the results of the election seem to reflect that people voted for candidates not because of the policies their parties stand for, but rather the region a party leader comes from. ${ }^{68}$ Second although that 1994 and 1994 general elections reveal that Malawian politics is conditioned by ethnicity, Bingu wa Muthalika's Democratic Progressive Party on the approach to the 2009 elections did well in the Tumbuka-speaking North, the Chewa-speaking Centre and the Sena-speaking South. ${ }^{69}$

Came the 2014 general elections, voting was patterned after tribal lines. According to Given Chichitike's article of 27 April 2014 appeared in Malawian News, Peoples' Party of the former President Joyce Banda accused Chewa Heritage Foundation for encouraging the Chewa people to vote for a Chewa tribe presidential candidate,

\footnotetext{
${ }^{64}$ Tim Hughs, Malawi: The Erratic Pulse of the Warm Heart of Africa Report number 5, The South Africa Institute of International Affairs.

${ }^{65} \mathrm{http}: / /$ maravi.blogspot.com/2009/11/nyasatimes-politics-of-tribe-in-malawi.html Date of access April, 14, 2015.

66 cf. Tsoka, Maxton Grant, 2009, A Country Turning Blue?: Political Party Support and the End of Regionalism in Malawi http://www.afrobarometer.org/publications/afrobarometer-briefing-papers/item/270-a-country-turning-blue-political-party-support -and-the-end-of-r Date of access May 2, 2015.

http://www.afrobarometer.org/publications/afrobarometer-briefing-papers/item/270-a-country-turning-blue-political-party-support -and-the-end-of-r D ate of access May 2, 2015.

${ }^{68}$ Daily Times, 19/5/94; 20/5/94; 8/7/94.

${ }^{69}$ http://maravi.blogspot.com/2009/11/nyasatimes-politics-of-tribe-in-malawi.html Date of access: May 2, 2015.
} 
Rev Dr Lazarus Chakwera. ${ }^{70}$ He quoted one of the party’s Deputy Director for women Catherine Banda saying:

There are some people of Chewa heritage who are moving door to door encouraging people to vote for a Chewa presidential candidate, so we are wondering who are they referring to as we are also of the the Chewa tribe, so as PP we have taken note of that and we are appealing to the Chewa heritage people to stop campaigning for a Chewa candidate. ${ }^{71}$

Although Chewa Heritage Foundation through its publicity secretary Mr. Jimmy Chikuni dismissed the claims saying they are baseless because the Chewa Heritage Foundation respect the rights which the Chewa people have in the country and that there is no way they can encourage them to vote for a particular candidate adding that their organization is non-partisan, ${ }^{72}$ the outcome of the 2014 general elections clearly proved that the cultural organizations are mobilized to get votes from tribal members.

Tribalism was also evidenced in the results of the 2014 president elections parliamentary elections. The People's Party obtained 56\% (highest) of the valid votes in the northern region, the Malawi Congress Party scored 58\% (highest) of the valid votes in the central region and the DPP got 56\% (highest) of the valid votes in the South. The same was true with the results of the parliamentary elections.

The statistical information above provides a clear indication that ethnicity is one of the important factors that play a significant role in Malawian politics. It is however undeniable truth that politicians hijack cultural associations in order to obtain political votes. The results also reflect that people voted for candidates not because of the policies of their parties but rather the tribe and region a party leader comes. There is cultural an identification with the political parties coming from tribal feeling.

\section{Conclusion: A Lesson to Be Drawn}

As this has shed more light on the question, why and how the Chewa Heritage Foundation and Mulhako wa Alhomwe while exercising their constitutional rights guaranteed in the constitution, associations are promoting tribalism, regionalism and nepotism and being used as campaign machinery by politicians, some few proposals as well as practical lessons from what is happening in Malawi are cited as conclusion. Perhaps it is important to request politicians, church leaders and economists that they must always remember that Malawi, as has been, will remain a multi-cultural nation. In view of this every ethnic grouping is constitutionally mandated to set up its non-political and non-governmental and non-religious association that will revive, preserve, protect its customs, values, beliefs and traditional practices especially those that will promote unity, peace, good governance, transparence and accountability in Malawi. It would be good to establish multi-ethnic organization that will act as an umbrella body for all the cultural organizations in an attempt to cut out all ethnic political boundaries. Malawi may remain a peaceful nation if political-party leaders stop favouring and trusting people that come from their tribe or region. Electorates should not devote their loyalty to the party and presidential aspirants that share their tribal identity. Having affirmed that tribalism has ruinous consequences, appointments in both public and private positions should be based on merit rather than on place of origin, region or tribe or political affiliation has been the case throughout the history of Malawi. Perhaps Malawians need to sing the following simple and powerful song, "Malawi is for everyone, good jobs must be given to every deserving citizens". In other words, political

\footnotetext{
${ }^{70} \mathrm{http}: / /$ www.themalawian.com/pp-acc Date of access: May 2, 2015.

${ }^{71} \mathrm{http}: / /$ www.themalawian.com/pp-acc Date of access: May 2, 2015.

72 http://www.themalawian.com/pp-acc Date of access: May 2, 2015.
} 
leaders must ensure that hiring of cabinet ministers, deputies ministers, principal secretaries, directors and board of directors of governmental does not favour a person on any cultural grouping either MWA or CHEFO. Perhaps there is need to speak and put into practice the very words of Dr. Kamuzu Banda who said, "So far as I am concerned, there is no Yao in this country; no Lomwe; no Sena; no Chewa; no Ngoni; no Nyakyusa; no Tonga; there are only 'Malawians'. That is all.,"73

\section{Reference}

Osei-Hwedie, B. (1998). The Role of ethnicity in multi-party politics in Malawi and Zambia. Journal of Contemporary African Studies, 16(2).

Electoral Commission, Presidential and Parliamentary Report 1994, Government Printer, Zomba.

Electoral Commission, Presidential and Parliamentary Report 1999, Zomba: Government Printer.

Electoral Commission, Presidential and Parliamentary Report 2004, Zomba: Government Printer.

Electoral Commission, Presidential and Parliamentary Report 2009, Zomba: Government Printer.

Electoral Commission, Presidential and Parliamentary Report 2014, Zomba: Government Printer.

GOM, 1995. Constitution of the Republic of Malawi. Zomba: Government Printer.

Ninth session of the Convention for the Safeguarding of the intangible Cultural Heritage Paris, France November 2014.

The CCAP-Nkhoma Synod, 1998. Pastoral Letter, The Christian Responsibility in A Democratic Country. Lilongwe: Nkhoma Press.

The CCAP Nkhoma Synod, 2012. Pastoral Letter, Exercising Our Faith through Prayer, In Our Time, In Our Nation. Lilongwe: Nkhoma Press.

The CCAP-Nkhoma Synod, 2003. Pastoral Letter called, "Reconsidering the Future of our Country, Malawi: Genuine Change required.” Lilongwe: Nkhoma Press.

The Pastoral Letter of the Catholic Bishops of Malawi, Living Our Faith, Lent 1992, Episcopal Conference of Malawi, Lilongwe.

Hughs, T. M.: The Erratic Pulse of the Warm Heart of Africa, Report number 5, The South Africa Institute of International Affairs.

Chirwa, W. (2014). Malawi democracy and political participation. Johannesburg: Open Society in Southern Africa.

Chirwa, W. (1999). Nandini Patel and Fidelis Kanyongolo, Democracy Report for Malawi, University of Malawi, Chancellor College, Zomba.

Chirwa, W. (1995). Regionalism, ethnicity and the national question in Malawi’, Southern Africa Political Economy Monthly, No. 8; in Kaspin, D. “The politics of ethnicity in Malawi’s democratic transition”, Journal of Modern African Studies, 33(4).

\section{News Papers}

The Lamp Magazine, Balata, Malawi.

The Daily Times, Blantyre, Malawi.

\section{Books}

Chirwa, W. C. (1998a). Democracy, ethnicity and regionalism: The Malawian experience, 1992-1996. In K.M. Phiri and K.R. Ross (Eds.), Democratization in Malawi: A stocktaking. Blantyre: CLAIM.

Harri, E. A democracy of chameleon: Politics and culture in the New Malawi. Blantyre: CLAIM.

Chirambo, R. M. (1998). Popular Music and Politics in Democracy of Chameleons: Politics and Culture in the New Malawi (ed.) Harri Englund: Blantyre, CLAIM.

Pauw, C. M. (1980). Mission and church: A brief history of the church of Central Africa presbyterian. DTh Thesis, University of Stellenbosch, South Africa.

\section{Internet Sources}

Afrobarometer, http://www.afrobarometer.org/publications/afrobarometer-briefing-papers/item/270-a-country-turning-blue-political-party-su pport-and-the-end-of-r

73 Leroy Vail and Landeg White, Tribalism in the Political History of Malawi blishing.cdlib.org/ucpressebooks/view?docId=ft158004rs\&chunk.id=nsd0e3729\&toc.id=endnotes\&toc.depth=1\&brand=eschol\&a nchor.id=d0e3743\#X Date of access: May 2, 2015. 
Chauwa,

A.

http://www.nyasatimes.com/2015/03/05/chewa-heritage-donate-k5m-worth-relief-to-flood-hit-lower-shire/

Chauwa,

A.

Nyasatimes, http://www.nyasatimes.com/2015/04/07/chewa-heriage-responds-to-kabwila-appeal-for-malawi-flood-disaster

Hastings Maloya, http://hastingsmaloya.blogspot.com/2012/04/bingu-high-class-leader-who-never.html/

Heritage Paris, France November 2014, http://whc.unesco.org/en/conventiontext/

Kishindo, P. A. K. (1997). "Malawi’s Social Development Policies: A Historical Review”, Bwalo: A Forum for Social Development, 1: 11-20. Kishindo, P. J. (1993). "Linguistic Diversity and National Unity”, UDF News 1, No. 44: South African Journal of African Languages 18: 85-92. Kool, H. E., Bloemkolk, D., Reeve, P. A. and Danner, S. A. (1990). HIV Seroposi.

Layson Godwin the Sibande, Nyasatimes Reporter, http://www.nyasatimes.com/2014/09/03/sept-1964-how-kamuzu-banda-and-mcp-planted-seed-of-tribalism/

Leroy Vail and Landeg, Tribalism in the Political History of Malawi, http://publishing.cdlib.org/ucpressebooks/view?docId=ft158004rs\&chunk.id=d0e3729

Malawi Digest Reporter, http://malawidigest.blogspot.com/2009/09/dr-munthali-ignored.html/

Malawi

Voice

Reporter,

http://malawivoice.com/2012/04/03/nkhoma-synod-letter-only-motivated-by-delayed-money-kaliati-74922/

Malawian Online News, http://www.themalawian.com/pp-acc/

Maravi post Reporter, http://maravi.blogspot.com/2009/11/nyasatimes-politics-of-tribe-in-malawi.html/

Maravi Post Reporter, http://maravi.blogspot.com/2009/11/nyasatimes-politics-of-tribe-in-malawi.html/

Menno Welling, http://www.mlambefoundation.org/en/newsitems/culturewhereto.html/

Mlambe Foundation, http://www.mlambefoundation.org/en/newsitems/mutharika.html

Mzati Nkolokosa, http://mzatinkolokosa.blogspot.com/2008/10/29/our-dying-languages.html/

Mzati Nkolokosa, http://mzatinkolokosa.blogspot.com/2008/10/our-dying-languages.html/

Mzimu wa Soldier: Contemporary Popular Music and Politics.

Ninth session of the Convention for the Safeguarding of the intangible Cultural.

Nyasatimes Reporter, http://maravi.blogspot.com/2009/11/nyasatimes-politics-of-tribe-in-malawi.html/

Nyasatimes Reporter, http://www.nyasatimes.com/2009/08/03/lomwe-becomes-buzz-word-for-malawis-employment-business

Nyasatimes Reporter, http://www.nyasatimes.com/2011/08/31/tribal-war-disguised-as-battle-for-governance-economic-issues/ Nyasatimes Reporter, http://www.nyasatimes.com/2011/10/08/mulhako-brings-forward-celebrations-oct-23rd/

Nyasatimes Reporter, http://www.nyasatimes.com/2013/06/28/kamanya-irks-lilongwe-chiefs-for-abusing-gule-wamkulu/

Nyasatimes Reporter, http://www.nyasatimes.com/2013/11/03/malawi-leader-advises-yao-chiefs-to-hold-heritage-indaba/

Nyasatimes Reporter, http://www.nyasatimes.com/2013/10/07/mulhako-wa-alhomwe-carnival-slated-for-october-27/

The General Conference at its seventeenth session Paris, 16 November 1972. http://whc.unesco.org/en/conventiontext/ Tsoka,

Maxton

Grant,

http://www.afrobarometer.org/publications/afrobarometer-briefing-papers/item/270-a-country-turning-blue-political-party-su pport-and-the-end-of-r/ 